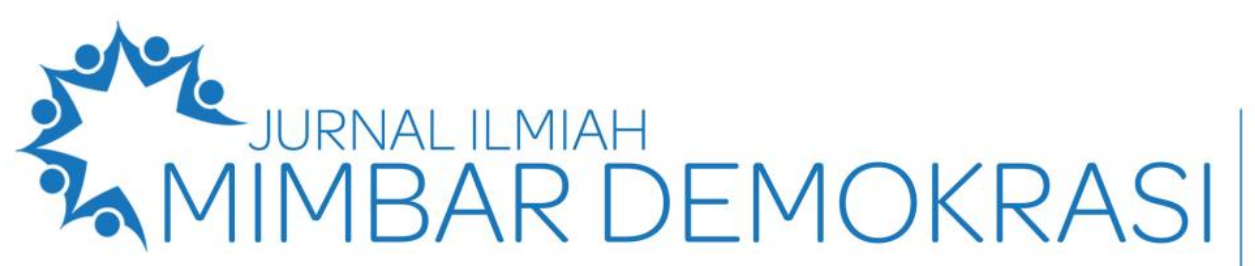

\author{
Vol. 19 No. 2 Tahun $2020 \mid$ Hal. $40-47$
}

\title{
Pemanfaatan Media Visual dalam Pembelajaran Pendidikan Pancasila dan Kewarganegaraan
}

\author{
Yulita Pujilestari a, 1*, Afni Susila b, 2 \\ a Dosen PPKn, Fakultas Keguruan dan Ilmu Pendidikan, Universitas Pamulang, Indonesia \\ b Alumni Prodi PPKn, Universitas Pamulang, Indonesia \\ 1 dosen00442@unpam.ac.id *; rafnychan86@gmail.com
}

*korespondensi penulis

Informasi artikel

\section{Diterima:}

04-03-2020

Disetujui:

17-04-2020

\section{Kata kunci:}

Penggunaan Media

Visual

Pendidikan Pancasila dan Kewarganegaraan Pembelajaran

\section{Keywords: Visual Media Utilization Civic Education Learning}

\begin{abstract}
ABSTRAK
Media visual yaitu alat peraga yang dipakai guru dalam peoses belajar mengajar sehingga dapat di nikmati oleh siswa melalui penglihatan atau panca indra mata. Penelitian ini adalah penelitian kualitatif deskriptif. Penelitian dilaksanakan di SMK Muhammadiyah 1 Ciputat, Tangerang Selatan. Subjek penelitian ini adalah siswa satu orang guru mata pelajaran Pendidikan Pancasila dan Kewarganegaraan dan tiga orang siswa kelas X Akuntansi. Teknik pengumpulan data yang dipakai yaitu observasi, wawancara, dan dokumentasi. Penelitian ini menghasilkan (1) antusiasme siswa dalam belajar mata pelajaran masih membutuhkan perhatian, tak lepas dari kendala baik kondisi kelas, maupun waktu belajar. Oleh karena itu guru harus mampu mengendalikan kelas agar keadaan kelas kembali terkendali dan siswa dapat belajar dengan konsentrasi, guru harus mampu membaca situasi kelas dengan baik. (2) Media visual dapat mempermudah guru dalam memberikan materi alam pembelajaran, media visual menampilkan gambaran konkret suatu materi, media visual juga dapat memusatkan motivasi siswa dalam belajar dan siswa mudah mengerti materi pelajaran, serta merangsang keaktifan siswa dalam belajar Pendidikan Pancasila dan Kewarganegaran. (3) Media visual dapat memberikan gambaran nyata suatu materi karena bukan hanya menampilkan teks, namun juga terdapat gambar, gerak, animasi yang menarik bagi siswa sehingga media visual agar dapat meningkatkan keinginan belajar mengajar siswa.
\end{abstract}

ABSTRACT

Visual media utilization in civic education learning. Visual media are visual aids used by the teacher in teaching and learning so that they can be enjoyed by students through vision or the five senses. This research is a descriptive qualitative research. The study was conducted at SMK Muhammadiyah 1 Ciputat, South Tangerang. The subjects of this study were students of one teacher of Pancasila and Citizenship Education subjects and three students of class $\mathrm{X}$ Accounting. Data collection techniques used are observation, interviews, and documentation. This research resulted in (1) the enthusiasm of students in learning subjects still requires attention, not free from constraints both in classroom conditions and learning time. Therefore, the teacher must be able to control the class so that the classroom situation is back in control and students can learn with concentration, the teacher must be able to read the class situation well. (2) Visual media can facilitate teachers in providing natural learning material, visual media display concrete images of a material, visual media can also focus student motivation in learning and students easily understand subject matter, and stimulate student activity in learning Pancasila and Citizenship Education. (3) Visual media can provide a real picture of a material because it not only displays text, but there are also images, movements, animations that are interesting for students so that visual media can increase the desire to learn and teach students

Copyright (C) 2020 (Yulita Pujilestari \& Afni Susila). All Rights Reserved

How to Cite: Pujilestari, Y., \& Susila, A. (2020). Pemanfaatan Media Visual dalam Pembelajaran Pendidikan Pancasila dan Kewarganegaraan. Jurnal Ilmiah Mimbar Demokrasi, 19(2), 40-47. DOI: 10.21009/jimd.v19i02.14334

This work is licensed under a Creative Commons Attribution-Share Alike 4.0 International License. Allows readers to read, download, copy, distribute, print, search, or link to the full texts of its articles and allow readers to use them for any other lanful purpose. The journal hold the copyright. 


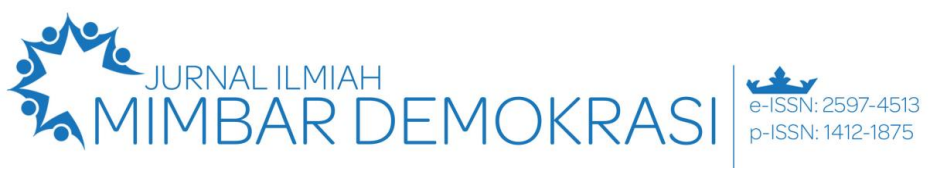

\section{Vol. 19 No. 2 Tahun 2020 | Hal. 40 - 47}

\section{Pendahuluan}

Setiap proses pendidikan tujuan utamanya agar menciptakan lulusan atau keluaran yang baik. Untuk menuju kesuksesan pendidikan untuk berpendidikan, itu harus melalui berbagai proses dan sistem yang baik. (Sanjaya, 2006) Proses atau sistem yang tersebut didalamnya yaitu proses belajar mengajar, sumber belajar, evaluasi dan alat. Bagian atau komponen didalamnya adalah yang termasuk guru, siswa, bahan atau bahan belajar dan media \& alat pembelajaran. Kehadiran adalah komponen penting yang harus dilaksanakan dalam proses belajar mengajar oleh seorang guru. Profesionalisme dan keterampilan guru begitu mempengaruhi hasil kegiatan belajar mengajar. Itu karena ketercapaian dalam proses belajar mengajar faktor yang paling mempengaruhi adalah guru. Maka bisa dikatakan tugas guru yaitu memberikan materi pelajaran kepada siswa lewat komunikasi dan interaksi. Proses pembelajaran yang tepat didukung oleh keadaan belajar yang tenang dan tertib tidak terlepas peran dari seorang guru. Keterkaitan komunikasi diantara siswa dan guru dapat dengan baik bekerja.

Komponen selanjutnya adalah siswa dalam kehadiran proses belajar mengajar. Siswa yaitu orang yang belajar dalam hubungan sosial dalam bentuk prosedur belajar mengajar. Proses pembelajaran terjadi dengan rangsangan dan respon antara seseorang dan lingkungannya, selanjutnya maksud dari belajar-mengajar yaitu mekanisme kompleks yang dialami oleh setiap orang dalam hidupnya. Karena itu, pembelajaran bisa terjadi kapan saja. Suatu tanda seseorang sedang belajar yaitu perbuatan yang dikarnakan oleh perubahan tingkat keterampilan, pengetahuan, dan sikap. Dan komponen yang berpengaruh untuk mendukung efektivitas pembelajaran lebih lanjut adalah pada penggunaan media saat dalam pembelajaran. Berkaitan adanya komunikasi dan media pembelajaran sangat membantu dalam implementasinya. Pemakaian media pembelajaran yang cocok dengan materi pembelajaran akan dapat membangkitkan minat baru dan keinginan, menghasilkan stimulasi dan motivasi proses belajar mengajar dan ini membawa pengaruh signifikan pada psikologi siswa. (Sukmadinata, 2004) Setiap rencana pembelajaran harus diatur dan dilakukan secara sistematis sehingga siswa dapat memusatkan perhatian mereka. Rencana pembelajaran direncanakan berdasarkan pada kebutuhan perilaku siswa diharapkan bisa mencapai tujuan yang ingin dicapai.
Dalam rencana ini bisa dikatakan bahwa media sudah sepantasnya tidak hanya dilihat sebagai bantuan bagi guru untuk mengajar, namun sebagai sarana untuk memberikan pesan dari sebagai pemberi pesan kepada penerima pesan. Media ini bisa digunakan oleh guru namun yang lebih penting bisa dipakai oleh siswa. Oleh karenanya, sebagai presenter dan distributor pesan-pesan media bisa mewakili guru yang memberikan informasi secara jelas, akurat dan menarik.

Media visual bisa membangkitkan minat belajar pada siswa karena dapat menghubungkan materi yang dipelajari oleh siswa dengan keadaan aslinya pada dunia nyata. "Media visual merupakan alat bantu mengajar yang dipakai guru dalam proses pembelajaran yang bisa dinikmati oleh siswa melalui visi atau panca indera."

Media visual dikatakan mampu menampilkan, hal-hal nyata dari fenomena yang dipelajari. Dengan memakai media visual ini, siswa tidak hanya membayangkan fenomena dalam pembelajaran yang dipelajari, guru bisa lebih mudah menunjukkan apa yang dimaksud dan apa yang akan disampaikan.

Pada kesempatan ini peneliti ingin meneliti penggunaan media visual dalam pembelajaran Pancasila dan Pendidikan Kewarganegaraan, pelajaran Pancasila dan Pendidikan Kewarganegaraan dikenal untuk pelajaran yang cenderung tidak menarik bagi siswa, stereotip ini terus berkembang dari generasi ke generasi.

Dari masalah yang timbul dari stereotype tentang Pendidikan Pancasila dan Kewarganegaraan perlu adanya solusi bagi tenaga pendidik untuk menciptakan image baru yang lebih baik untuk Pendidikan Pancasila dan Kewarganegaraan, karena Pendidikan Pancasila dan Kewarganegaraan merupakan pembelajaran yang penting didalam membentuk sebuah warga negara yang hidup untuk selaras dengan pancasila dan UUD 1945 (Hamidi \& Lutfi, 2010). Dalam pengunaan media visual diharapkan akan menambah semangat belajar siswa pada mata pelajaran Pendidikan Pancasila dan Kewarganegaran.

Hamalik dalam Arsyad (2008) menjelaskan media kominukasi merupakan alat komunikasi untuk memperlancar dan mendapatkan hasil yang maksimal dala berkomunikasi.

Setelah itu, Asnawir \& Usman (2002) mengatakan bahwa, media adalah alat penyaluran pesan sehingga bisa merangsang prasaan, pikiran, 
dan ketertarikan siswa hingga bisa termotivasi terjadinya jalannya belajar pada dirinya.

Selanjutnya bisa dikatakan bahwa media yaitu alat yang bisa dipakai untuk menyalurkan informasi yang berhubungan dengan pembelajara supaya materi yang berikan bisa diterima oleh siswa dengan baik.

Kemudian menurut Djamarah dan Zain (2002) media adalah sumber belajar dan dengan mengutip Winataputra (2001) menggabungkan sumber belajar menjadi lima kategori, adalah manusia, buku/perpustakaan, media massa, alam lingkungan dan media pendidikan.

Dilihat dari penjelasan diatas bisa dikatakan bahwa media pembelajaran yaitu media alat untuk menggapai tujuan pembelajaran tersebut, alat tersebut berupa buku, koran, majalah, televise, radio dan lain sabagainya, termasuk perbuatan yang dapat di contohkan oleh tenaga pendidik dalam proses belajar mengajar.

Dalam proses belajar media merupakan salah satu hal penting sebagai pendukung untuk memberikan pesan pembelajaran kepada peserta didik, karena media pembelajaran merupakan sebuah alat atau perangkat yang di perlukan oleh guru untuk menyampaikan informasi berupa ilmu pengetahuan kepada peserta didiknya.

Media adalah alat yang wajib ada ketika kita ingin memperlancar pekerjaan. Setiap orang pasti menginginkan pekerjaanya bisa menyelaraskan dengan baik dan dengan hasil yang memuaskan. Media adalah alat penyalur informasi belajar atau penyalur pesan.

Pemakaian media pembelajaran yang tepat juga merupakan strategi guru dalam meberikan pembelajaran kepada peserta didik, media berkaitan dengan dengan sumber belajar dalam arti luas sumber belajar bisa berupa pesan, alat (media), teknik, dan lingkungan. Bisa diartikan bahwa media pembelajaran bisa memudahkan sebagai alat yang dipakai guru dalam proses pembelajaran, media dalam melakukan sesuatu seperti halnya dalam memberikan pembelajaran kepada peserta didik.

Alasan yang pertama berkaitan dengan manfaat pengajaran dalam proses belajar siswa antara lain: Metode yang digunakan dalam mengajar akan lebih bervariasi, bukan hanya menggunakan metode ceramah yang bisa menmbulkan rasa bosan kepada siswa, Bahan pembelajaran bisa menumbuhkan semangat siswa sehingga siswa termotivasi untuk menguasai tujuan pembelajaran, pembelajaran bisa lebih nyaman dan dapat memnangkitkan motivasi belajar siswa, Peserta didik akan lebih termotivasi dalam pembelajaran, karena akan banyak kegiatan yang dilaksanakan seperti melakukan, mendemonstrasikan dan lain-lain.

Karena siswa terlebih anak-anak masih berpikir konkrit, semua yang disampaikan oleh guru harus dijelaskan dengan memperlihatkan apa yang sedang dijelaskan, lalu media visual adalah sumber belajar yang didalamnya terdapat pesan yang diciptakan agar terkesan dalam bentuk kombinasi teks, foto, gerak, dan animasi yang diselaraskan dengan usia siswa.

Media visual ini sesuai untuk memberikan tujuan informasi dalam bentuk rangkuman yang dipadatkan. Media visual bisa diartikan sebagai media pemberi pesan antara gagasan dan fakta secara, kuat, jelas dan terpadu, melalui kombinasi menyampaikan kata-kata dan gambar. Poster yaitu penyatuan diantara tulisan dan gambar dalam satu ruang lingkup yang menginformasikan mengenai satu atau dua ide pokok, poster seharusnya diciptakan dengan gambaran dekorasi dan huruf yang nyata dan jelas, Karikatur dan kartun yaitu garis yang dicoret dengan simpel yang mengarahkan kepada suatu hal yang penting. Sedangkan kartun ide utamanya yaitu mengupload rasa lucu dan kesan utamanya yaitu senyum dan tawa. Kesan pesan dan humor yang disampaikan dari karikatur dan kartun mengakibatkan pesan yang diberikan awet dalam ingatan anak.

Media adalah sarana untuk menumbuhkan salah satu aktivitas belajar mengajar. Oleh karna itu diperlukan dalam memilihnya harus cermat dan tepat agar bisa dipakai secara tepat guna.

Ada empat fungsi media visual, menurut Levied dan Lents dalam Arsyad (2008) yaitu: Fungsi atensi media visual yaitu inti, yang mengarahkan dan membawa perhatian siswa untuk berkonsentrasi kepada pelajaran yang berhubungan dengan makna visual yang nmenyertai atau ditampilkan teks isi materi pelajaran. Dengan media gambar yang diproyeksikan lewat overhead projector bisa menarik siswa pada mata pelajaran sehingga semakin besar untuk mengingat pelajaran, temuan-temuan yang diungkapkan oleh peneliti mengenai fungsi kognitif media visual mengenai lambang visual atau gambar mempermudah pencapaian tujuan untuk mengingat dan memahami informasi atau pesan yang terdapat dalam gambar, Fungsi afektif media visual bisa tampak dari tingkat kenyamanan siswa ketika sedang belajar dan membaca teks yang bergambar, Fungsi kompensatoris media visual yang menyampaikan konteks untuk dapat 


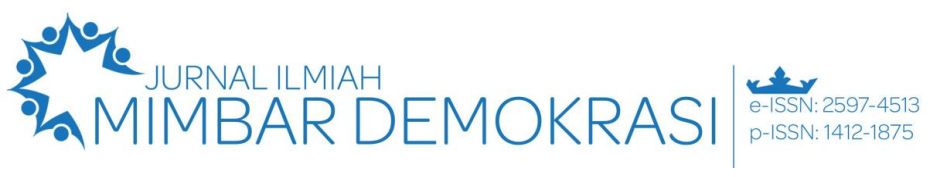

\section{Vol. 19 No. 2 Tahun 2020 | Hal. 40 - 47}

mengerti teks yang lemah dalam membaca untuk menggunakan informasi dalam teks dan bisa mengingat kembali.

Dari keempat fungsi yang diambil Levied dan Lentz, dapat disimpulkan media visual penting dalam proses belajar. Sehingga dengan memakai media visual bisa meningkatkan semangat belajar siswa, sehingga tujuan pembelajaran bisa tercapai selain itu dipakai media dalam pembelajaran guru bisa membagi pesan kepada siswa yang lebih baik. Dengan belajar langsung serupa itu pastinya termasuk proses belajar yang bermanfaat, karna dengan suatu tersebut kemungkinan persepsi kesalahan akan bisa dihindari. Pemakaian media pembelajaran juga bisa menayangkan objek yang membantu terlalu besarnya yang tidak mungkin bisa ditampilkan di dalam kelas.

Media pengajaran akan membantu proses belajar siswa dalam pengajaran yang dapat dianggap bisa membantu untuk motivasi belajar siswa dan meningkatkan hasil belajar yang akan dicapai. Adapun manfaat dalam memakai media pembelajaran visual dalam proses belajar mengajar, antara lain: Metode pengajaran akan lebih bervariasi, tidak hanya menggunakan metose ceramah yang bisa membuat siswa menjadi bosan, Bahan pengajaran lebih nampak jelas artinya sehingga siswa bisa memahaminya. Dan bahan ajar dibuat sesuai dengan tujuan pembelajaran, Pengajaran bisa menumbuhkan perhatian siswa sehingga yang bisa meningkatkan semangat belajar, Siswa bisa lebih banyak melaksanakan aktivitas belajar seperti mengamati, melakukan dan lain-lain, Kualitas hasil belajar bisa ditinggikan apabila integrasi kata dan gambar sebagai media pembelajaran bisa member pesan elemen-elemen pengetahuan melalui cara yang tersusun dengan baik, spesifik dan jelas.

Lainnya manfaat media pembelajaran visual juga memiliki pengaruh yang sangat penting bagi terlaksananya proses belajar mengajar. Peran media pembelajaran visual dalam proses belajar mengajar dapat dilihat sebagai berikut: Alat untuk menyampaikan bahan pengajaran ketika guru memberikan pelajaran. Dari sini media dipakai oleh guru untuk penjelasan materi verbal tentang bahan pengajaran, Alat untuk menyelesaikan masalah dalam belajar diteliti lebih dalam oleh para siswa dalam proses belajarnya, Sumber belajar bagi siswa, artinya media tersebut terdapat bahan bahan yang harus dipelajari para siswa baik individual maupun kelompok, kelompok. kelompok ini akan banyak membantu tugas guru dalam proses beljar mengajar.
Dalam proses belajar mengajar, pemakaian media pembelajaran yang selaras dengan materi pembelajaran yang akan diberikan bisa menumbuhkan motivasi belajar siswa yang berujung pada meningkatkannya prestasi belajar siswa. Kesamaan media pembelajaran, khususnya media pembelajaran visual, dengan materi pembelajaran maka akan meringankan pemakaian media pembelajaran tersebut. Tetapi, apabila pemakaian media pembelajaran tersebut tidak selaras dengan materi pembelajaran, maka akan menimbulkan penghambat media pembelajaran.

Dalam menggunakan media pembelajaran visual untuk kecakapan guru, yakni:

a. Faktor-faktor yang bisa menjadi pendukung didalam pemakaian media pembelajaran visual diakibatkan keunggulan media pembelajaran visual dengan media pembelajaran lain. Dibawah ini ada beberapa factor pendukung pemakaian media pembelajaran visual, yakni: Media pembelajaran visual mempunyai keunggulan bisa menayangkan gambaran nyata tentang benda atau kejadian. Sehingga siswa bisa lebih mengerti materi pelajaran karena melihat secara langsung, Media pembelajaran visual mempunyai kemampuan untuk menampilkan gambaran yang bisa dilihat dengan jelas oleh siswa sehingga member kemudahan bagi guru dalam memberikan materi yang diberikan oleh guru pada siswa, Media pembelajaran visual siswa bisa menunjukan motivasi karena tampilannya yang menarik, Media pembelajaran visual bisa membantu siswa dengan gampang membandingkan dua benda yang berbeda sifat, bentuk, ukuran dan warnanya, Media pembelajaran visual mempunyai kemampuan tersendiri. Sehingga bisa menyuguhkan kembali obyek-obyek atau kejadian dengan berbagai perubahan (memanipulasi) selaras dengan keinginan yang dibutuhkan oleh siswa.

b. adapun Faktor penghambat penggunaan media pembelajaran visual, yaitu antara lain: Tidak semua pokok bahasan mata pelajaran bisa diterangkan dengan menggunakan suatu media pembelajaran visual, Tidak semua lembaga pendidikan memiliki kelebihan dalam menyediakan perangkat atau peralatan media pembelajaran visual. Hal ini disebabkan untuk menjalankan media ini perlu keterampilan dan sarana yang khusus. Masih sering terjadi penafsiran-penafsiran dalam pesan-pesan visual tidak bisa dihindari. Seorang guru dalam mempergunakan pesan-pesan visual harus 
berhati-hati tanpa penjelasan sebelumnya karena akan mengakibatkan kekeliruan kepada siswa.

Dari penjelasan di atas, dapat disimpulkan yaitu sudah tugas seorang guru untuk mengambil keputusan, dalam menentukan penggunaan media pembelajaran visual dalam memberikan materi pembelajaran kepada siswa. harus diingat bahwa pembelajaran media ini memiliki hal positif jika dilihat dengan media pembelajaran yang lainnya. Namun keunggulan itu tidak berarti apa-apa ketika guru tidak bisa menyesuaikan media materi yang disampaikan dalam pembelajaran, sehingga akan mengakibatkan hal buruk pada proses belajar mengajar yang dijalankan

\section{Metode}

Borg dan Gall (1996) seperti yang di kutip pada Moleong (2007), menyatakan metodologi kualitatif sebagai prosedur penelitian yang bisa menciptakan data deskriptif yang berupa katakata berupa kata tertulis ataupun lisan dari orangorang dan prilaku yang diamati. Jadi penelitian kualitatif yaitu penelitian yang menciptakan kesimpulan data yang didalamnya ada rinci, lain menghasilkan data yang berupa angka-angka. Dilihat dari segi prosedur dan pola yang telah dijalani oleh peneliti, penelitian ini pada jenis ini tegolong penelitian kualitatif.

Sesuai dengan defenisi tersebut di atas, Kirk dan Miller (1986) dalam Moleong (2007), mendefenisikan mengenai penelitian kualiatif merupakan cara tertentu dalam ilmu pengetahuan sosial yang secara fundamental bergantung dengan pengamatan pada manusia baik dalam lingkungannya maupun dalam dalam peristilahannya. Penelitian kualitatif bertujukan untuk mengerti hal-hal sosial dari perspektif partisipan, partisipan yaitu individu atau kelompok yang diajak berwawancara, di dalam observasi, diminta menyampaikan data, pendapat, pemikiran dan persepsinya. Sehingga bisa diterangkan mengenai penelitian kualitatif yaitu termasuk penelitian yang menggunakan wawancara, pengamatan, dan dokumentasi pada obyek penelitian maka menghasilkan data yang menerangkan secara lengkap mengenai obyek penelitian.

Selain itu pola penelitian yang dipakai pada penelitian ini yaitu pola deskriptif. Pola ini merupakan penelitian yang "hanya bisa melukiskan keadaan obyek atau persoalannya dan tidak di maksudkan untuk menarik atau mengambil kesimpulan yang berlaku umum". Menurut teori penelitian, pola deskriptif itu ada dua sifat, yaitu bersifat eksploratif dan brsifat developmental. Tetapi dalam penelitian ini memakai pola deskriptif eksploratif yaitu, "bertujuan untuk menggambarkan keadaan atau status fenomena". Selanjutnya yang bisa dirangkum adalah penelitian ini memakai pola deskriptif eksploratif, bahwa pola penelitian yang menerangkan secara lengkap mengenai persitiwa atau status fenomena obyek penelitian dan tidak mencari kesimpulan yang berlaku secara umum. Adapaun kesimpulan yang diambil yaitu suatu gambaran objek yang terjadi pada saat penelitian.

Pola deskriptif ini dipakai untuk mengkaji permasalahan penelitian yang berhubungan dengan Pemakaian media pembelajaran visual dalam Pembelajaran Pendidikan Pancasila dan Kewarganegaraan di SMK Muhammadiyah 1 Ciputat.

Pemilihan informan yaitu selaras dengan kerangka penelitian ini sehingga pemilihan objek sesuai dengan tujuan untuk meneliti mengenai Penggunaan Media Visual pada Pendidikan Pancasila dan Kewarganegaraan. Dalam penelitian ini yang menjadi objek penelitian yaitu guru dan siswa SMK Muhammadiyah 1 Ciputat.

Pada informan penelitian kali ini informasi yang diambil oleh peneliti adalah guru PPKn ( yang meliputi guru kelas X) dan peserta didik.

Metode Pengumpulan Data dengan Metode Observasi yaitu dalam metode ini, peneliti mengadakan pengamatan dan pencatatan secara langsung. Posisi peneliti dalam metode ini yaitu sebagai pengamat sekaligus sebagai pencatat atau pelaku langsung dari observasi yang dilakukan, Metode Wawancara/Interview. Menurut Gunawan (2013) wawancara yaitu suatu percakapan pada suatu problem tertentu, ini yaitu tanya jawab lisan, dimana dua orang atau lebih berhaddapan secara fisik yaitu disebut dengan Wawancara Terstruktur dipakai sebagai teknik pengumpulan data, ketika peneliti atau pencari data telah tau dengan jelas mengenai informasi apa yang bisa didapat. Maka dari itu wawancara dalam melaksanakan pengumpul data sudah membuat instrument berupa pertanyaan-pertanyaan penelitian tertulis yang alternatif jawabannya pun telah disiapkan dan Wawancara tidak terstrukutur yaitu wawancara yang bebas yaitu dimana peneliti tidak memakai sebuah pedoman wawancara yang diterapkan berupa garis-garis besar pada permasalahan yang bisa ditanyakan, Metode Dokumentasi tersebut dan dipakai dalam melaukakan untuk mendapatkan informasi mengenai keadaan profil sekolah, sarana dan prasarana, aturan menelaah dan kedisiplinan 


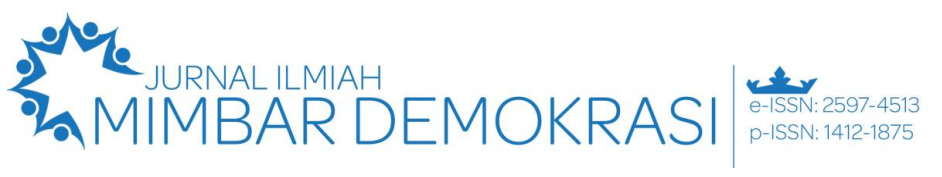

\section{Vol. 19 No. 2 Tahun 2020 | Hal. 40 - 47}

konteks sosial yang bisa menerangkan subyek atau obyek yang diteliti agar mendapatkan informasi yang maksimal.

\section{Hasil dan pembahasan}

Penelitian kualitatif memiliki prosedur yang harus di jalani, berikut ini merupakan adalah prosedur yang di harus laksanakan dalam penelitian kualitatif :

1. Menetapkan Fokus Penelitian

syarat penelitian kualitatif berdasarkan pada logika berfikir induktif maka pelaksanaan penelitiannya bisa bersifat sangat fleksibel, penelitian kualitatif harus melewati prosedur penelitian yang ada. Sama dengan penelitian kuantitatif, hal pertama yang dijalankan sebelum memulai seluruh tahap penelitian kualitatif yaitu pertanyaan penelitian. Pertanyaan penelitian yang di batasi oleh sebuah permasalahan yang tertuang dalam fokus penelitian, pertanyaan penelitian yaitu tentang hal-hal yang menjadi pokok permasalahan dan hal yang akan di cari jawabannya dalam penelitian tersebut.

2. Menentukan Setting dan Subyek Penelitian

Dalam penelitian kualitatif setting yaitu hal yang telah ditentukandan sangat penting pada saat mentukan fokus penelitian. Setting dan subyek penelitian sesuatu yang sudah ditentukan sejak awal penelitian. Setting penelitian ini memberi kelompok yang akan diteliti dan melihat kondisi fisik dan sosial subyek penelitian.

Sebelum melakukan penelitian, peneliti menemui kepala sekolah SMK Muhammadiyah 1 Ciputat untu mengajukan permohonan penelitian di sekolah tersebut dan menyerahkan surat permohonan pengajuan untuk penelitian yang telah di tanda tangani oleh kepala program studi Pkn Universitas Pamulang dan pihak sekolah SMK Muhammadiyah 1 Ciputat menyetujuinya. Peneliti menemui guru Pkn untuk mendiskusikan penelitian yang akan di lakukan, mempersiapkan bahan ajar, media visual yang akan digunakan dan persiapan lainnya.

Data dari hasil penelitian pada penelitian ini bisa lewat observasi, wawancara mendalam yang diadakan oleh peneliti dalam kurun waktu bulan Agustus 2018. Seluruh informan yang melakukan wawancara mendalam yaitu guru Pkn dan siswa kelas X Akuntansi SMK Muhammadiyah 1 Ciputat, Tangerang Selatan. Peneliti menjalankan wawancara dengan guru PKn dan beberapa siswa kelas X Akuntansi yang menjadi sumber data dalam penelitian ini yang disebut juga dengan informan.
Cogan (2007) menyatakan bahwa civic education adalah mata pelajaran dasar yang dirancang untuk mempersiapkan para generasi muda warga negara untuk dapat melakukan peran aktif dalam masyarakat kelak setelah mereka dewasa. Sedangkan citizenship education mencakup pengalaman belajar di sekolah dan luar sekolah bisa melalui keluarga, organisasi keagamaan atau melalui media massa. Dengan demikian istilah citizenship education mengandung implikasi yang lebih luas dibandingkan dengan civic education yang distuktur di sekolah formal. (Wahab \& Sapriya, 2007)

Antuasiasme siswa dalam belajar pada mata pelajaran masih kurang, karena ada beberapa problem, salah satu penyebabnya yaitu karena jam pelajaran pada jam terakhir, sehingga semangat yang kurang dalam belajar. Dalam hal ini guru sangat berpengaruh penting mengatasi masalah kebosanan siswa seperti pengemasan materi yang menarik, memberikan joke atau games pada saat siswa mulai terlihat bosan, dalam hal ini guru di tuntut untuk membaca situasi kelas agar proses belajar bisa berjalan dengan lancar dan pelajaran pun dapat di terima dengan baik oleh setiap siswa.

Pada pembelajaran yang menggunakan media visual, siswa dilatih untuk dapat mengingat, mengungkapkan kembali pengetahuan, membandingkan dan mengambil keputusan. Dalam proses belajar mengajar siswa dibantu untuk mengungkapkan idenya secara jelas melalui kegiatan yang dilakukan sehari-hari."Siswa menyusun kalimat berdasarkan gambar yang sudah tersedia. Siswa menemukan konsepkonsep baru sehingga mereka menjadi lebih paham dan bersemangat dalam belajar karena mereka mengalaminya sendiri.

Penggunaan Media Visual Dalam Pembelajaran Pkn di SMK Muhammadiyah I Ciputat, tentang peran penggunaan media visual dalam pembelajaran Pkn yaitu sebagai berikut:. Peran media visual dalam pembelajaran selain membantu guru dalam menyampaikan pelajaran juga membuat siswa lebih aktif dalam belajar, karena media visual itu menarik seperti halnya power point, dengan tampilan gambar, warna, jadi lebih real bukan sekedar bercerita namun ada contoh konkritnya, pada intinya media visual itu menarik perhatian siswa, jadi sangat membantu di dalam berjalannya proses pembelajaran

Media visual adalah salah satu media pembelajaran yang bersifat efektif karena media visual dapat memberikan sebuah kesan yang nyata bagi para peserta didik pada saat mempelajari suatu materi, sehingga siswa tertarik 
untuk belajar, selain itu media visual juga membantu guru dalam menyampaikan materi pembelajaran dengan mudah di pahami karena dikemas berupa teks dan sebuah gambar.

Hal tersebut diatas sesuai dengan manfaat media visual dalam pembelajaran yaitu menarik perhatian siswa, membantu guru dalam memberikan materi pembelajaran, siswa dapat lebih aktif, dan berakhir pada kualitas hasil belajar.

Meningkatkan keinginan belajar siswa merupakan hal yang begitu penting dalam pembelajaran,karena hal ini bersangkutan dengan penerimaan siswa bagi materi yang di sampaikan oleh guru.

Media visual menarik perhatian siswa sehingga meningkatkan rasa keinginan tahuan siswa terhadap pelajaran yang disampaikan, karena konkrit jadi pelajaran yang di sampaikan mudah untuk di mengerti, karena dapat dilihat secara langsung berupa teks, gambar, gerak, animasi, jadi merangsang siswa untuk memperhatikan, sehingga dalam proses belajar siswa terpusatkan perhatiannya terhadap pelajaran karena bantuan media visual ini, terlebih pada zaman sekarang, anak-anak kan sudah mengenal hp yang biasanya menampilkan gambar, dan terlihat bahwa mereka betah banget memegang hp berjam-jam karena menarik untuk di lihat, begitu juga media visual dalam belajar, terutama pada pelajaran pkn yang muatannya berupa teori, media visual sangat membantu. Media juga harus di sesuaikan dengan materi pelajaran, tidak semua materi pada pelajaran dapat di menggunakan media visual. Penggunaan media visual dalam pembelajaran $\mathrm{Pkn}$ memotivasi siswa untuk belajar dan siswa lebih mudah diarahkan karena perhatiannya terpusat terhadap pembelajaran dan mudah juga memahami apa yang kita sampaikan.

Media visual dapat menumbuhkan keinginan belajar siswa pada pembelajaran Pkn. Penggunaan media visual dalam pembelajaran Pkn merupakan sebuah tuntutan agar siswa bisa memiliki keinginan dalam belajar, karena Pkn yang akrab dengan image pelajaran yang membosankan, dengan penyajian materi menggunakan sebuah media visual akan bisa menumbuhkan keinginan belajar siswa karena praktis dan mudah di pahami.

Media mempunyai pengaruh penting dalam proses pembelajaran, meningkatkan dunia pendidikan menuntut guru mengupgrade media pembelajaran yang bisa dipakai dalam proses belajar mengajar selaras dengan kebutuhan peserta didik. Media visual yaitu media yang bisa dipakai dalam proses belajar mengajar, terutama pada pembelajaran Pkn. Berdasarkan hasil wawancara tersebut terhadap informan, yaitu guru mata pelajaran Pkn dan siswa SMK Muhammadiyah 1 Ciputat.

Antusiasme siswa dalam pembelajaran adalah yang penting dalam proses pembelajaran, khususnya mata pelajaran Pkn, antusiasme siswa yang kurang dalam belajar Pkn dapat terjadi karena faktor lingkungan seperti kondisi kelas dan waktu pembelajaran dilaksanakan, untuk itu guru harus memiliki kreatifitas untuk membuat suasana baru agar belajar yang kondusif sehingga siswa antusias dalam belajar. Dengan mengemas pembelajaran dengan menarik agar siswa antusias untuk mengikuti pelajaran.

Pemakaian media begitu penting dalam proses pembelajaran $\mathrm{PKn}$, peran pengunaan media visual dalam pembelajaran yaitu memberikan sebuah kesan nyata bagi siswa pada saat belajar. Media visual membantu guru dalam memberikan materi dalam pembelajaran dengan mudah di pahami. Hal tersebut sesuai dengan manfaat media visual itu sendiri yaitu, menarik perhatian siswa, memudahkan guru dalam memberikan materi, membuat semangat siswa untuk aktif, dan berakhir pada kualitas hasil belajar.

Media visual menumbuhkan keinginan aktivitas belajar siswa dalam pembelajaran Pkn, dengan uraian yang konkrit yang terdapat pada media visual, dengan contoh yang nyata terhadap suatu materi yang dipelajari dalam Pkn, maka akan meningkatkan rasa keingin tahuan siswa terhadap pembelajaran $\mathrm{PKn}$, dan siswa dapat lebih mudah diarahkan.

Dapat ditarik kesimpulan bahwa media visual memiliki sebuah peran untuk menumbuhkan keinginan belajar siswa dalam pembelajaran $\mathrm{Pkn}$, memberikan motivasi agar aktif belajar, guru diberi kemudahaan dalam menyampaikan materi dalam proses belajar. Pemilihan media yang tepat perlu di perhatikan oleh tenaga pendidik sehingga memberikan kesan positif terhadap peserta didik.

\section{Simpulan}

Antuasiasme siswa dalam belajar pada mata pelajaran Pkn di SMK Muhammadiyah masih memerlukan perhatian hal itu terjadi tak lepas dari kendala baik kondisi kelas serta situasi maupun waktu belajar yang membuat menurunnya antuasiasme siswa diantaranya adalah kebosanan siswa dalam belajar. Dalam hal ini guru harus bisa 


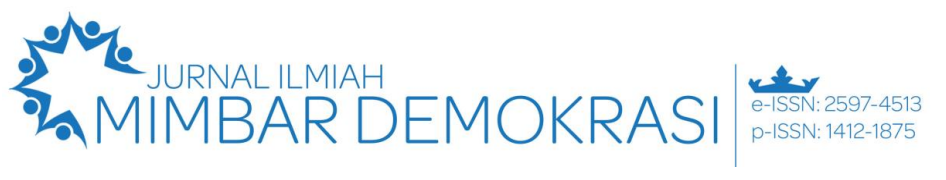

Vol. 19 No. 2 Tahun 2020 | Hal. 40 - 47

mengendalikan kelas agar kondisi kelas selalu kembali kondusif dan siswa mampu belajar dengan konsentrasi, guru harus mampu membaca situasi dan kondisi kelas dengan baik.

Pemakaian media visual dalam pembelajaran PKn memudahkan guru dalam memberikan pembelajaran, karena media visual yang menampilkan, gambaran materi yang real terhadap astusisme dipelajari oleh siswa di kelas tentunya sangat membantu dalam proses pembelajaran. pemakaian media visual sudah berjalan dengan baik dan sangat membantu guru dan siswa dalam proses aktivitas pembelajaran. Media yang dipakai berupa power point dengan tampilan warna dan materi yang dikemas dengan menarik sehingga penggunaan media visual sudah terlaksana dengan baik.

Media visual dapat memberikan gambaran nyata suatu materi media visual bukan hanya tampilan teks, namun juga terdapat gambar, gerak dan animasi, hal ini memberikan kesan bagi siswa, sehingga media visual ini dapat membangkitkan keinginan siswa dalam belajar, dan perhatian siswa terpaku pada pembelajaran selain itu media visual juga lebih simpel dan mudah di pahami oleh siswa. Image mata pelajaran Pendidikan Pancasila dan Kewarganegaraan yang cenderung membosankan dapat teratasi dengan adanya penggunaan media visual ini.

\section{Referensi}

Arsyad, Azhar. (2008). Media Pembelajaran. Jakarta: Raja Grafindo Persada

Asnawir, B. U., \& Usman, M. B. (2002). Media pembelajaran. Jakarta: Ciputat Pers.

Cogan, J., \& Derricott, R. (Eds.). (2014). Citizenship for the 21st century: An international perspective on education. Routledge.

Djamarah., \& Zain. (2002). Strategi Belajar Mengajar. Jakarta: Rineka Cipta

Gall, M. D., Borg, R. W., \& Gall, P. J. (1996). Educational research: An instruction. New York, White Plains: Longman.

Gunawan, Imam. (2013). Metode Penelitian Kualitatif Teori dan Praktik. Jakarta: Bumi Aksara

Hamidi, J., \& Lutfi, M. (2010). Civic education: antara realitas politik dan implementasi bukumnya. PT Gramedia Pustaka Utama.
Kirk, J., Miller, M. L., \& Miller, M. L. (1986). Reliability and validity in qualitative research (Vol. 1). Sage.

Moleong, L. J. (2007). Metode penelitian kualitatif. Bandung: Remaja Rosdakarya.

Sanjaya, W. (2006). Strategi pembelajaran berorientasi standarproses pendidikan. Jakarta : Kencana Prenada Media

Sukmadinata, Nana Syaodih. (2004). Landasan Psikologi proses Pendidikan. Bandung: PT. Remaja Rosdakarya

Wahab, Abdul Aziz., Sapriya. (2007). Teori dan Landasan Pendidikan Kewarganegaraan. Bandung: Alfabeta.

Winataputra, U. S. (2001). Model-modelpembelajaran inovatif. Jakarta: $P A U$. 